\title{
New technologies applied to neonatal transport
}

\author{
Michele Panico \\ From XXI Congress of the Italian Society of Neonatology \\ Palermo, Italy. 24-26 September 2015
}

As neonatal care in the tertiary setting advances, neonatal transport teams are challenged with incorporating the innovations into their work environment. Some advancements over the last years involve communication, respiratory management, hypothermia, newborn comfort.

\section{Communication}

The communication gold standard is the implementation of advanced technologiesas establishment of arealtime telepresence clinical network that allows online collaboration between primary care physicians working in community hospitals and critical care transport teams on moving vehicles. These participants will be able to work in collaborationduring the evaluation, stabilization and transfer of critically ill newborns.

\section{Respiratory management}

Many major respiratory treatments and the equipment required have been adapted for transport. There is evidence that new methods of non invasive ventilation support have significantly changed RDS management in preterm infants. Further perspectives for neonatal transport teams involve the assessment of NIV strategies. If the infant is less than 28 weeks, has an air leak, or has persistentpulmonaryhypertension, the team may elect to place the infant on high frequencyventilation. To date two modes of HFV has been studied in the care of infants: high frequency oscillatory ventilation (HFOV) and high frequency jet ventilation (HFJV). However, transport with the HFO is not a current option as it does not have external battery power. HFJV can be used for transport as it has an external battery. After ventilation is established, the team assesses the need for surfactant. The administration of surfactant prior to transport determine a significantly greater drop in oxygen requirement and appears to be

\footnotetext{
Correspondence: michele.panico@libero.it

Neonatal Intensive Care Unit and Neonatal Emergency Transport, A.O.R.N. Sant'Anna e San Sebastiano, Caserta, Italy
}

\section{Newborn comfort}

All babies showed higher levels of discomfort during transport. Discomfort is increased by mechanical ventilation or other invasive procedures. Analgo-sedation improve outcome of newborn during transport.

Published: 24 September 2015

\section{References}

Falco L, Panico M: Vademecum del Trasporto Neonatale d'Emergenza., III Edizione 2008

2. Qureshi A, Shih E, Fan I, Carlisle J, Brezinski D, Kleinman M, Guttag J: Improving patient care by unshackling telemedicine: adaptively aggregating wireless networks to facilitate continuous collaboration. Amiaannusymp proc 2010, 2010:662-666.

3. Panico M, Abbate L, Ansalone A, Ausanio G, Bernardo I, Brescia D, Capasso A, Crispino F, D'Angelo D, Grassia C, Mastroianni R, Rossi V, Vendemmia M, Falco P, Clarizia F, Romano A: Creazione di una rete informatica tra centri nascita, centrale operativa del Trasporto Neonatale Nazionale della S.I.N., poster P024. 2014

4. Coe $\mathrm{KL}$, Jamie SF, Baskerville RM: Managing common neonatal respiratory conditions during transport. Adv Neonatal Care 2014, 14(Suppl 5):S 3-10. 
5. Mainali ES, Greene C, Rozycki HJ, Gutcher GR: Safety and efficacy of highfrequency jet ventilation in neonatal transport. J perinatol 2007 27(10):609-613.

6. Mildenhall LF, Pavuluri NN, Bowman ED: Safety of synthetic surfactant use before preterm newborn transport. J paediatr child health 1999, 35(6):530-535.

7. Lutman D, Petros A: Inhaled nitric oxide in neonatal and paediatric transport. Early Hum Dev 2008, 84(11):725-729.

8. De Vries $L S$, Hellström-westas $L$ : Role of cerebral function monitoring in the newborn. Arch dis child fetal neonatal Ed 2005, 90(3):f 201-207.

9. Chaudhary R, Farrer K, Broster S, McRitchie L, Austin T: Active Versus Passive Cooling During Neonatal Transport. Pediatrics 2013, 132:841.

10. Falco L, Panico M, Falco P: Analgosedazione del neonato in ventilazione meccanica nel Trasporto Neonatale d'Emergenza. XVII Congresso Nazionale della S.I.N., poster P041. 2011.

doi:10.1186/1824-7288-41-S1-A26

Cite this article as: Panico: New technologies applied to neonatal transport. Italian Journal of Pediatrics 2015 41(Suppl 1):A26.

\section{Submit your next manuscript to BioMed Central} and take full advantage of:

- Convenient online submission

- Thorough peer review

- No space constraints or color figure charges

- Immediate publication on acceptance

- Inclusion in PubMed, CAS, Scopus and Google Scholar

- Research which is freely available for redistribution

Submit your manuscript at www.biomedcentral.com/submit 